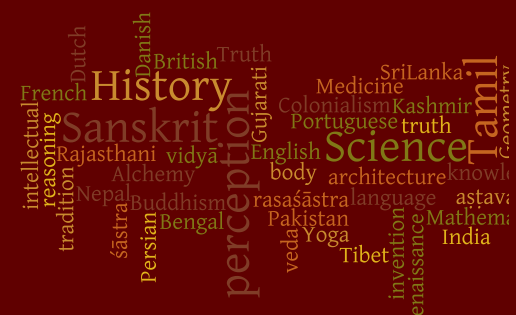

\title{
History of Science in South Asia
}

A journal for the history of all forms of scientific thought and action, ancient and modern, in all regions of South Asia

\section{Bhāskara I on the Construction of the Armillary Sphere}

Peng Lu

MLA style citation form: Peng Lu, "Bhāskara I on the Construction of the Armillary Sphere," History of Science in South Asia 3 (2015): 1-19.

Online version available at: http://hssa.sayahna.org/. 


\section{HISTORY OF SCIENCE IN SOUTH ASIA}

A journal for the history of all forms of scientific thought and action, ancient and modern, in all regions of South Asia, published online at http://hssa.sayahna.org

Editorial Board:

1. Dominik Wujastyk, University of Vienna, Vienna, Austria

2. Kim Plofker, Union College, Schenectady, United States

3. Dhruv Raina, Jawaharlal Nehru University, New Delhi, India

4. Sreeramula Rajeswara Sarma, formerly Aligarh Muslim University, Düsseldorf, Germany

5. Fabrizio Speziale, Université Sorbonne Nouvelle - CNRS, Paris, France

6. Michio Yano, Kyoto Sangyo University, Kyoto, Japan

Principal Contact:

Dominik Wujastyk, Editor, University of Vienna

Email:〈hssa@sayahna.org〉

Mailing Address:

Krishna GS, Editorial Support, History of Science in South Asia

Sayahna, JWRA34, Jagathy, Trivandrum 695014, Kerala, India

This journal provides immediate open access to its content on the principle that making research freely available to the public supports a greater global exchange of knowledge.

Copyrights of all the articles rest with the respective authors and published under the provisions of Creative Commons Attribution-ShareAlike 4.0 License.

The electronic versions were generated from sources marked up in $\mathrm{AT}_{\mathrm{E}} \mathrm{X}$ in a computer running GNU/LINUX operating system. PDF was typeset using $X_{H} T_{E} X$ from TEXLive. The base font used for Latin script and oldstyle numerals was TEX Gyre Pagella developed by GUst, the Polish TEX Users Group. 


\title{
Bhāskara I on the Construction of the Armillary Sphere
}

\author{
Peng Lu
}

\section{INTRODUCTION}

$\mathrm{T}$ he armillary sphere is said to have been invented by the Greek astronomer Eratosthenes (276-194 BC). ${ }^{1}$ Ptolemy's Almagest (second century AD) contains a detailed description of the armillary sphere. However the armillary sphere described in Sanskrit texts on astronomy, from the seventh century onwards, is substantially different from the Greek armillary sphere. ${ }^{2}$

In Sanskrit, the armillary sphere is known as gola or gola-yantra. The word gola denotes primarily the "sphere." Āryabhața and other astronomers use this term in the sense of "spherics" as opposed to ganita "mathematical in general." Thus Āryabhata's Äryabhatìya (early sixth century CE, henceforth АBH) has four chapters named Daśagìtikā (Ten Gīti Stanzas Giving Parameters), Ganita (Mathematics), Kālakriyā (Time-reckoning), and Gola (Spherics). Here the chapter on Gola,

expounds Āryabhatata's cosmology and geography, explains the apparent motions of the heavenly bodies, and gives solutions for problems in spherical trigonometry and rules for computing eclipses. ${ }^{3}$

In addition, the term gola also denotes the armillary sphere consisting of several rings to represent the orbits of the celestial bodies in the heavens. ${ }^{4}$

I wish to offer my special thanks to Professor S. R. Sarma for encouraging me to write this paper and for his constructive comments on the earlier version of this paper. I would also like to express my gratitude to my teacher Professor Michio Yano for his constant support. Finally my thanks are due to Wei Liu of Shanghai Conservatory of Music, China, for producing the 3DCG figures for my paper.

${ }^{1}$ Bryant 1907: 18.

${ }^{2}$ Ôhashi 1994: 272.

3Pingree 1981: 18.

${ }^{4}$ Āryabhata uses the word gola once (АВH 4.22) in the sense of the celestial globe also, but such usage is rare. All the other uses of the word gola in ABH $\left(1.1,2.7,4.5^{-} 7,4.15,4.16,4.23,4.39\right)$ refer to spherics. 
Brahmagupta discusses the armillary sphere in his Brāhmasphuțasiddhānta (628 AD, henceforth BSs), 5 but there he deals more with spherics than with the actual instrument. ${ }^{6}$ About the same time (629 AD), Bhāskara I also describes the armillary sphere in his commentary on the Äryabhatìya (henceforth вAB).

Subsequently Lalla (eighth century) in his Sișyadhīorddhidatantra, Śripati in his Siddhāntaśekhara (1039), Bhāskara II in his Siddhāntaśiromaṇi (1150) described the construction of the armillary sphere. Interestingly enough Lalla and others do not discuss the armillary sphere in the chapter Yanträdhyāya along with other astronomical instruments, but in a separate chapter called "tying or assembling the [various rings of the armillary] sphere" (gola-bandha).

Among the descriptions of the armillary sphere to be found in Sanskrit texts on astronomy, Bhāskara I's description is unique because it explains in detail how to construct the armillary sphere step by step: how to prepare a wooden ring by joining two or three strips of wood after making cuts or indents in the thickness at the ends, how to assemble two or more rings with appropriate indents at the points of intersection and so on. In this connection, he mentions three varieties of cuts (cheda) to be made for assembling the rings. Such practical details are not given in other Sanskrit texts. At the end of the passage, Bhāskara mentions that the armillary sphere he envisages is a free-standing one, but some others prefer to place the lower half of the armillary sphere in a pit dug in the level ground so that the horizon ring is level with the surface of the ground (see paragraph 20 of Bhāskara I's text and Figure 20 below).

\section{BHĀSKARA'S DESCRIPTION OF THE GOLA}

Before commenting on the Gola chapter of the Āryabhațīya, Bhāskara describes the armillary sphere ( $g$ ola) first, because this instrument will be useful in explaining the statements on the spherics (gola) in the Äryabhatīya. In this paper, we follow the text of Bhāskara's commentary as given in the critical edition of 1976 by K.S. Shukla (pp. 240-243) and translate the passage on the armillary sphere and add explanatory notes. Bhāskara's description is so detailed that it is possible for us to reconstruct a gola-yantra with wooden rings. The successive stages of the construction are shown by different figures. We have added serial numbers to the paragraphs, and corrected the irregular sandhis that occur in Shukla's text.

[I1 1] कालक्रियानन्तरं गोलं, “त्रीणि गद़ति गणितं कालक्रियां गोलम्" इत्युक्तत्वात्। गम्यते ज्ञायतेऽस्मादिति गोलम्। किं पुनरस्माद्यम्यते? ग्रहभ्रमणधरित्रीसंस्थानादीनि सर्वम्। (11. 6-8, p. 240)

${ }^{5}$ BSS 21.49-69.

${ }^{6}$ Ôhashi 1994: 262. 
"Immediately after the [chapter on] reckoning the time (kālakriyā) [comes] the [chapter on] spherics (gola), for it was said [by Āryabhata] that "he discusses three [topics], [namely] mathematics (ganita), reckoning of time (kālakriyā), [and] spherics."7 [The word] "gola" is derived from [the verb] "gamyate" [which means by it everything is to] be understood (jñayate). What then can be understood from this [spherics]? The revolutions of the planets, the position of the earth, and all such matters."

[II 2] एवं परमार्थजिज्ञासवो ह्यसत्यपूर्वकं सत्यं प्रतिपद्यन्ते। तद्यथा भिषजो ह्युत्पल्डनालादिषु सिरावेधनादीनि प्रतिपद्यन्ते, यज्ञशास्त्रविद्: शुष्केष्ट्या यज्ञादीनि [प्रतिपद्यन्ते], वैयाकरणाः प्रकृतिप्रत्ययलोपागमवर्णविकारादिभिः साधुराब्द् प्रतिपद्यन्ते, एवमत्रापि सांवत्सराः वृत्तरालाकासूत्रावलम्बकादिभिः क्षेत्रगणितविरोषैः पारमार्थिकं गोलं प्रतिपद्यन्ते। तस्माद्दिझ्मात्रप्रद्रानमेवैतदारभ्यते, अराक्यत्वादरोषप्रदर्शानस्य। को हि चित्रयान्निमेषोन्मेषाद्यपि चित्रयति।(11. 8-14, p. 240)

"Thus those who wish to understand the highest truth (paramārtha) will understand the reality (satya) through the fictitious [assumption] (asatya). For example, physicians understand piercing (vedhana) the vessels of the body (sirā) or other [treatments] by [practicing] on the lotus stalk (utpalanāla) or some other things; those who know the science of sacrifice [understand] sacrifice and other [issues] through mock (śușka) rite (iști) (i.e., play-acting); grammarians understand the correct [usage of] the words (sādhu-śabda) through basic form (prakrti), affix (pratyaya), elision (lopa), augment (āgama), phonemes (varna), modification (vikāra), and so on. In the same manner, here also, astronomers (sāmvatsara) comprehend the real celestial sphere (gola) through certain [concepts] of geometry (kșetraganita-viśeșa) like the ring (vrtta), the rod (śalākā), the thread (sütra), the plumb line (avalambaka), and so on. ${ }^{9}$

Therefore, [here] the demonstration of only the part will be undertaken, for it is impossible to demonstrate everything. While painting, who can paint the closing and opening in the flutter of the eyes?"

\footnotetext{
${ }^{7} \mathrm{ABH} 1.1 \mathrm{~cd}$ : आर्यभटस्त्रीणि गद्ति गणितं कालक्रियां गोलम्॥

${ }^{8}$ The contents in the square brackets [] in the Sanskrit text are by Shukla 1976.

${ }^{9}$ In his commentary on the Bss, Prthūdaka uses the same argument with almost the same wording. See Ikeyama 2002: 20: यथा वैयाकरणाः प्रकृतिप्रत्ययागमलोपवर्णविकारागमादिभिःसाधुत्वं शाब्दुस्य प्रतिपद्यन्ते याज्ञिकाश्च तु श्रुवादिभिर्यज्ञादीन्भिषग्वराश्चोत्पलानलादिभिः सिरादिवेधान्त्रतिपद्यन्ते एवमिहापि सांवत्सरा ज्याधनुःःरारभुजकोटिकर्णावलम्बकरालाकावृत्तादिभिः क्षेत्रगणितविशोषेश्च सत्यपूर्वकेः सत्यं ग्रहभ्रमणधरित्रीसंस्थानादिकं गोलतत्त्वं प्रतिपद्यन्ते।
} 

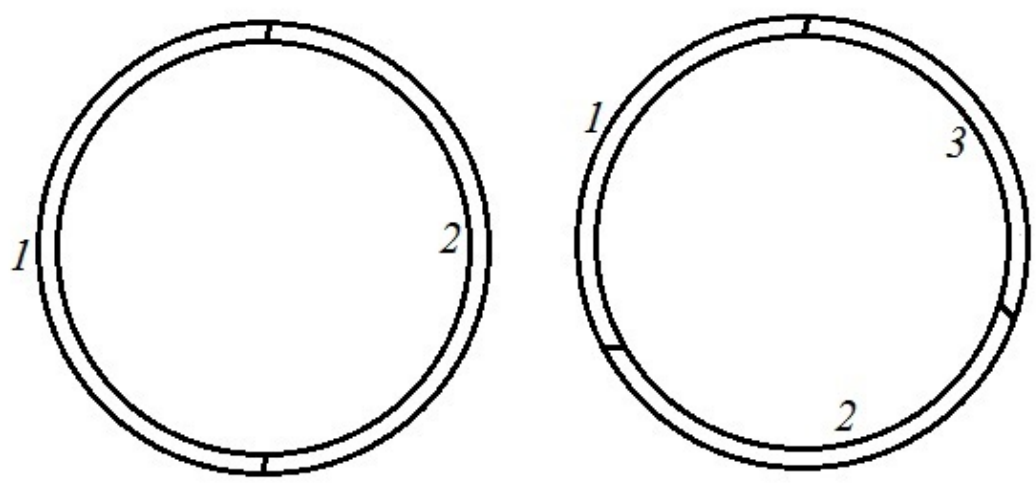

Figure for II 3: Assembling the two or three segments into a ring.

\section{[I13] तस्माच्छ्रीपर्णिवश्चुलकाष्ठयोरन्यतममर्धवृत्तं चकस्वरूपं काकचिकेवृत्तमेकं निष्पादयेत्।}

ततः सुघटितार्धवृत्तद्वयेन त्रिभिर्वा सुघटितवृत्तराकलै: वृत्तमेकं निर्मापयेत्। (11.14-16, p. 240)

"Therefore, he should make the carpenters (krākacika) prepare a half circle (ardhavrtta) made out of the timber of either Śrīparn̄i (Gmelina arborea, Roxb.) or Vañcula (Dalbergia ougeinensis, Roxb., or Calamus rotang, L., or Saraca indica, L.), [and then] one [full] circle or ring which has the shape of a wheel. Then he should make [the carpenters] produce a ring made either with two well-crafted (sughatita) half circles or three well-crafted segments of the circle."10

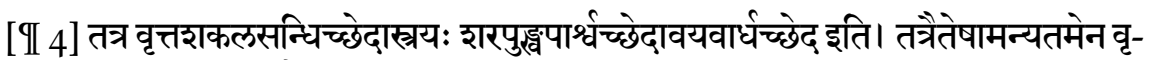
त्तशाकलान्यन्योन्यं घटयेत्। (11. 16-18, p. 240)

"In this process, there are three [kinds] of cuts (cheda) for joining the segments of the circle, called arrow-shaft (śarapunkha), cutting the side (pārśvaccheda), and cutting half of the component (avayavärdhaccheda). With one of these [cuts] the segments of the circle should be joined with each other."11

[I1 5] ताम्रकीलकैस्तत्रैवं निष्पन्नमेकं वृत्तं पूर्वापरं निधाय द्वितीयं दक्षिणोत्तरमुपर्यधश्च जनितस्व-

स्तिकं, स्वस्तिकसम्पाते च मण्डलद्वयमर्धच्छेदेन छित्वा तथा संयोज्यं यथैकमेव वृत्तं लक्ष्यते। तौ

\footnotetext{
${ }^{10}$ This sentence seems to be redundant since that a ring has already been produced by the preceding sentence.

${ }^{11}$ We do not know the real meaning of the three different types of cuts mentioned by Bhāskara, because these terms do not appear in any other astronomical text. According to the literal meaning of the names, we draw the imaginary pictures in the Figure for $\mathbb{I} 4$.
} 


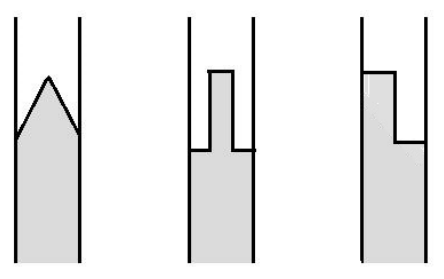

Figure for II 4: Three kinds of cuts (reconstructed).

\section{विहितार्धच्छेदेन (स्वस्तिकचतुष्टयं प्रवेइय निश्चलं निद्ध्य) ${ }^{12}$ ताम्रकीलकैर्निश्चल्कीक्रियते। (11. 18- 21, p. 240)}

"Set one ring prepared in this manner [by joining the segments firmly] with copper nails (tämrakilaka) in the east-west [direction] and another [ring] in the southnorth so that there are intersections (svastika) [of the two rings] above and below. Then, at the [two] points of intersections [above and below], join the two rings after cutting with half cut (ardhacheda) [in the thickness] so that it looks like one circle (i.e., the thickness at the two joints should be the same as the thickness of each ring). The two [rings which are joined] by the half cut prescribed above (vihitārdhaccheda) should be made firm with copper nails."

[I1 6] ततस्तयोर्मण्डलयोर्बहिः परिकरवत् दिक्कतुष्टयजनितस्वस्तिकमन्यं तथैवार्धच्छेदेन स्वस्तिकचतुष्टयं प्रवेशय निश्रलं निद्ध्यात्। (11. 1-2, p. 241)

"Then one should [set up] another [ring] like a girdle (parikara) outside [and around] these two rings so that it has four intersections at the four cardinal directions; one should insert it by the half cuts [in the thickness of the ring] as before at the four intersections and make it firm."

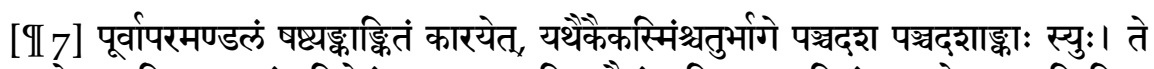
चाहोरात्रघटिकाः। एवं परिशोषं मण्डलुद्वयमपि, एकैकं षष्टिरातत्रयाङ्कितं [कारयेत्]। तानि विषुवत्[याम्योत्तरक्षितिज]मण्डलानि। (11. 2-5, p. 241)

"He should mark the east-west ring with 6o marks (aika) so that in each quarter [of the ring] there are 15 marks. These [marks] are the ghatikās of the day and night. In the same way, each of the two remaining rings is also [marked] with 360 marks. These [three are called] the equator ring (visuvat), [the meridian or the north-south ring (yāmyottara), and the horizon ring (kșitija)]."

\footnotetext{
${ }^{12}$ The words which are put in brackets () are redundant here and not translated, because up to here we only have got two intersections above and below, not four. These are repeat part of the next sentence.
} 


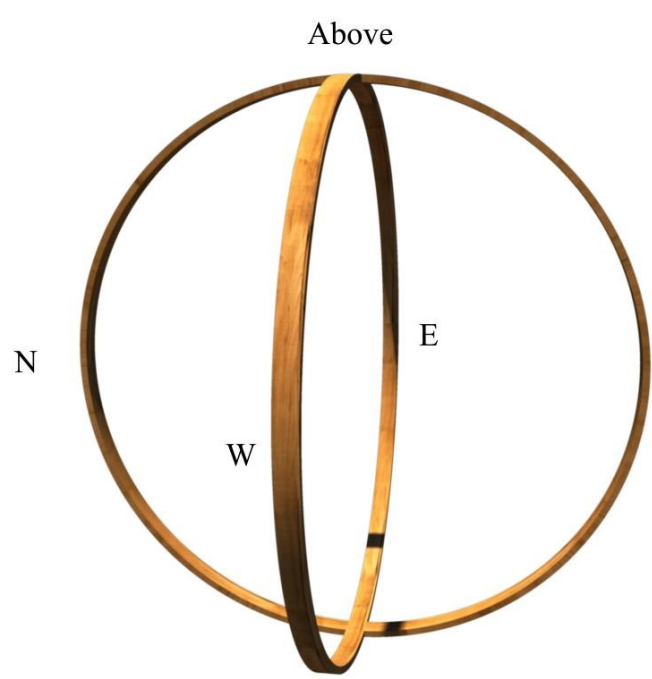

Below
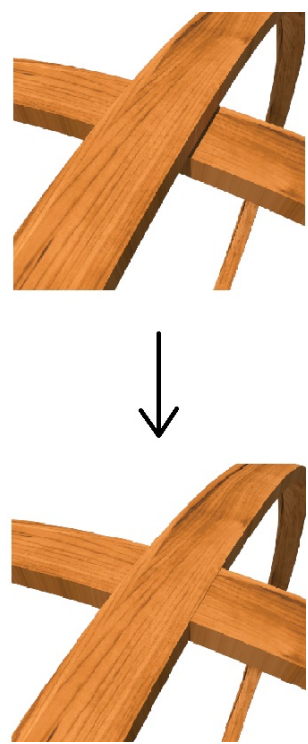

Figure for II 5: Two intersections of two rings.

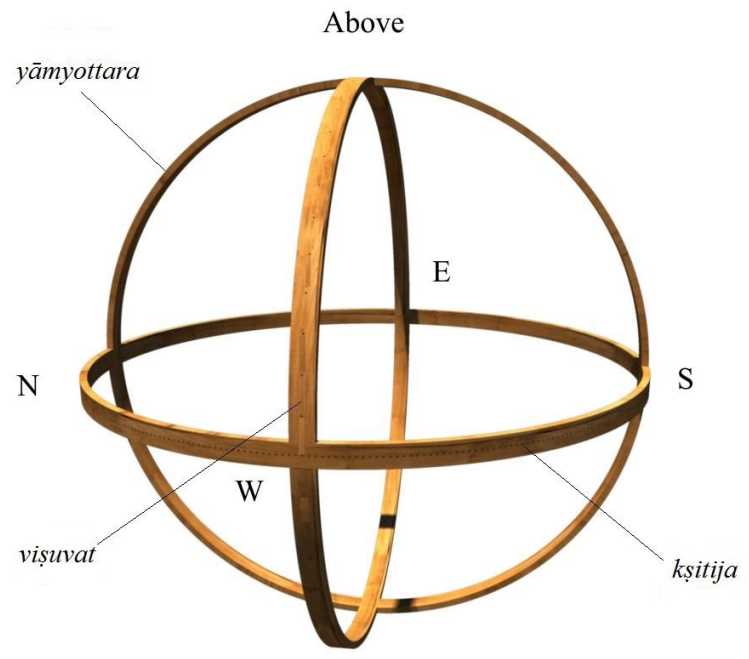

Below

Figure for II 7: Rings of the equator (viṣuvat), meridian (yāmyottara), and horizon (kșitija). 

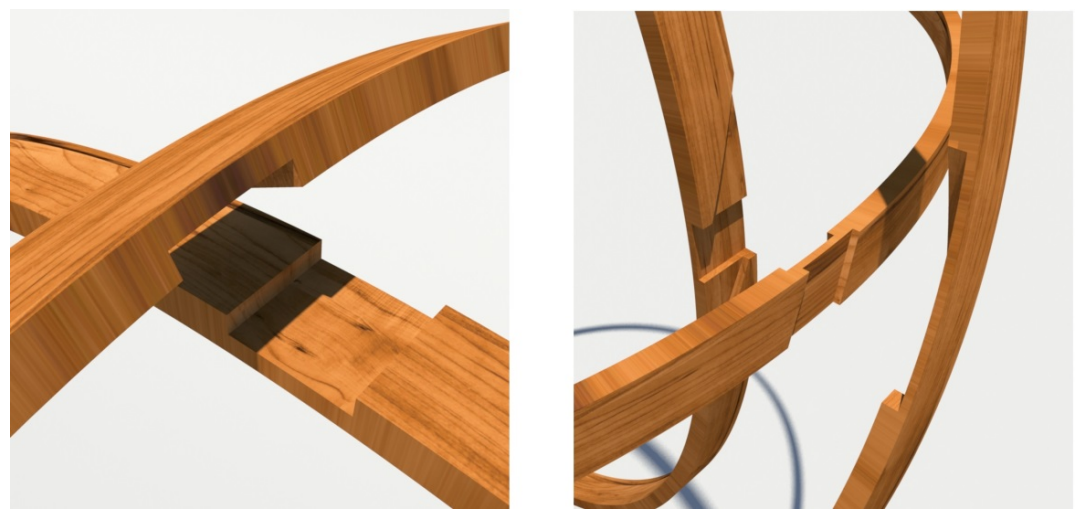

Figure for II 8 \& 9: Half cut (ardhacheda) and one-third cut (tribhāgacheda).

[II 8] तत्तुल्यमेवापरं मण्डलं षष्टिरातत्रयाङ्कितं पूर्वस्वस्तिके अपरस्वस्तिके च तिर्यक्रिभागच्छेद् कृत्वा द्वौ त्रिभागौ मण्डलप्रदेशास्य स्वस्तिकं घटयेत्। यथा वा मण्डलत्रयसम्पातमेकमेव लक्ष्यते तथावछेद्: कल्पनीयः। (11. 5-8, p. 241)

"One should [make] another ring of the same size marked by 360 [marks] and possessed of an oblique one-third cut at the eastern and western intersections; he should join the two one-thirds with the intersection of a point of the ring. Or the cut (avacheda) [in the thickness of the rings] should be made in such way that [the thickness at] the intersection of the three rings should look like [the thickness of] one single [ring]."13

[II 9] पूर्वापरदुक्षिणोत्तरमण्डलयोर्योऽधः स्वस्तिकः तस्मादुत्तरेण उत्तरशालाकायां चतुर्विंशातिभागे तथैवार्धच्छेदेन स्वस्तिकं कारयेत्। उपर्यपि तथैवोपरिस्वस्तिकाद्दक्षिणेन [दक्षिण]रालाकायां चतुर्विंशातितमे भागे स्वस्तिकं कारयेत्। (11. 8-11, p. 241)

"Towards the north from the lower intersection of the east-west ring and the south-north ring, at the distance of 24 degrees on the northern rib [of the southnorth ring], he should make an intersection (svastika) [with the fourth ring] by the half cut [in the thickness] (ardhaccheda) as before. On the upper part also, he should make, in the same manner, an intersection on the [southern] rib [of the south-north ring] at the 24 th degree from the upper intersection towards the south."

\footnotetext{
${ }^{13}$ This can be achieved by cutting the thickness of the three rings at the point of intersection in such a way that only one-third of the thickness remains in each ring. When these three rings are carefully joined, the combined thickness at the intersection is equal to the thickness of a single ring.
} 


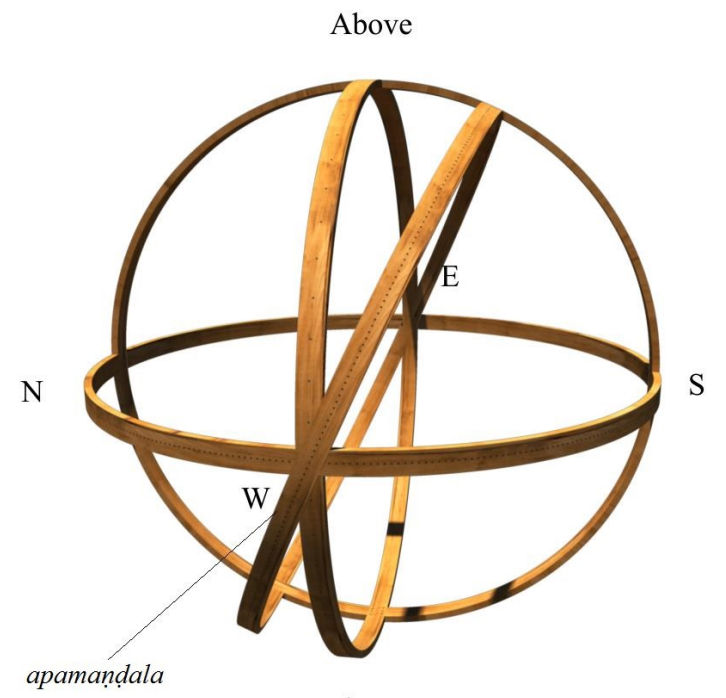

Below

Figure for II 10: Addition of the ecliptic ring (apamandala).

[I10] सर्वत्र निश्वलीकरणं ताम्रकीलकेः। एवं तिर्यग्राशिपदो व्यवस्थितः। स एवापमण्डलमित्युच्यते। (11. 11-12, p. 241)

"Everywhere the [joints must be] made firm with copper nails. Thus [the circle of] the zodiac signs (rāsi-pada) is placed obliquely. It is called the ecliptic ring (apamandala)."

\section{[II11] तावत्प्रमाणमेवान्यन्मण्डलं सज्चारि यत्र चन्द्रमसः सम्पातो वर्तते तस्मिन्बध्वा तत उत्तरेण परतो नवतितमे भागे यथा चार्धपश्चमभागास्तस्य चापक्रममण्डलस्य चान्तरे भवन्ति तथा विधाय पातभागे चक्रार्धान्तरे बध्रीयात्। एवं ततो द़क्षिणेन नवतितमे भागे अर्धपश्चमा भागास्तस्यापक्रम- मण्डलस्य च यथाऽन्तरे भवन्ति तथा निद्ध्यात्। (11. 13-17, p. 241)}

"He should tie another ring of the same size, which is movable (sañcārin), ${ }^{14}$ at the point where the moon's node (sampäta) is situated and arrange it in such way that to the north of that [node] at its ninetieth degree there is an interval of four and half degrees between it and the ecliptic ring (apakrama-mandala); he should join [it] at the degree of the node (pāta-bhāga) at an interval of half a circle

\footnotetext{
${ }^{14}$ The word "sañcārin" (movable) means that this ring representing the moon's orbit should not be fixed firmly in the structure like the ecliptic ring, because the intersection of this ring and the ecliptic ring, which is called "pāta" (the moon's node), is moving constantly along the ecliptic ring. According to АВН 1.3C, the moon's node performs 232226 revolutions in a yuga, that is to say, one revolution in 18.6 years. But Bhāskara does not explain how to make this ring "movable."
} 


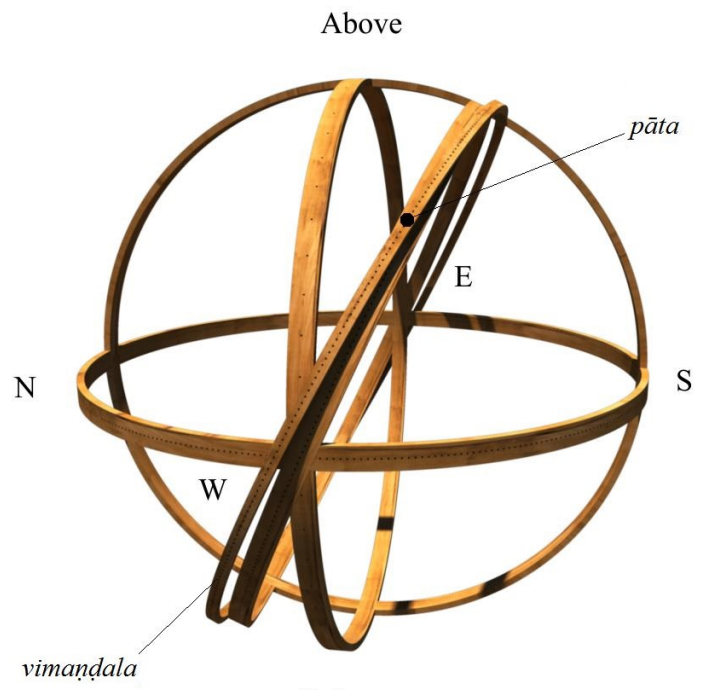

Below

Figure for II 12: Orbit of the moon (vimandala).

(cakrārdhāntara). In the same manner, he should arrange [the ring] to the south of that [node] at its ninetieth degree so that there is an interval of four and half degrees between it and the ecliptic ring."

[I1 12] एवं तद्विमण्डलम, तदेव विक्षेपमण्डलुमित्युच्यते। एवमन्येषामपि स्वेभ्यः स्वेभ्यः पातभागेभ्योऽपि मण्डलानि। बुधशुक्कयोः शीघ्रोचाभ्याम्। (11. 17-20, p. 241)

"Thus it is the orbit [of the moon] (vimandala); it is also called the circle of deflection (viksepa-mandala). ${ }^{15}$ Likewise, rings should be inserted for other [planets] at their own degrees of nodes. In the case of Mercury and Venus, [the orbit circles are made] according to their singhroccas." ${ }^{\prime 16}$

[1113] स्वाहोरात्रमण्डलान्यपि सश्चारीणि --- विषुवत उत्तरेण मेषापक्रमकाष्ठतुल्यान्तरे पूर्वापरायतं मण्डलं मेषस्याहोरात्रमण्डलं, वृषान्तापक्रमतुल्यकाष्ठान्तरे वृषस्य, मिथुनान्तापक्रमतुल्यकाप्ठान्तरे मिथुनस्य, तान्येवोत्कमेण कर्कटकसिंहकन्यानाम; एवं [विषुवतो] दक्षिणेन तुलावृश्चिकधनुषां स्वाहोरात्रमण्डलानि, तान्येवोत्क्रमेण मकरकुम्भमीनानाम्। (11. 20-24, p. 241)

"[All] the day circles (svāhorātra-mandala) are also movable (sañcārin). From the equator (visuvat) towards the north at a distance equal to the arc on the declination circle (apakrama-kāsțha) for Aries (meșa), a ring [should be added to the ecliptic ring] with stretches in the east-west direction (pürväparāyata); it is the day

\footnotetext{
${ }^{15}$ Or the latitude circle in modern astronomy.

${ }^{16}$ In the case of inner planets (i.e., Mercury and Venus), their śighroccas (i.e., apex of fastest motion) are regarded as the planets' mean heliocentric positions.
} 


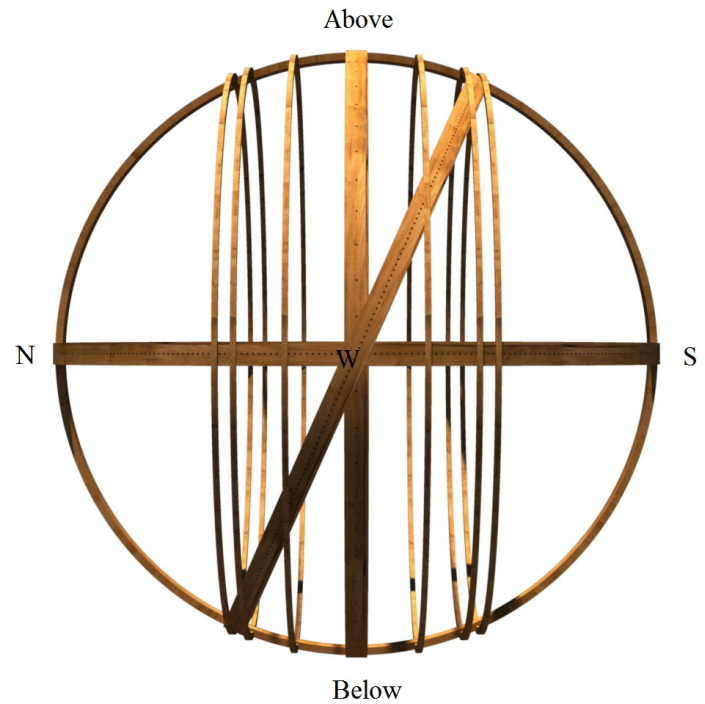

Figure for II 13: Addition of the day circles (svāhorātra-mandala).

circle of Aries. At a distance equal to the arc on the declination circle that ends in Taurus (vrsa), [a ring should be added to the ecliptic ring], it is [the day circle] of Taurus. At a distance equal to the declination arc that ends in Gemini (mithuna), [a ring should be added to the ecliptic ring], it is [the day circle] of Gemini. The same [rings] belong also to Cancer (karkațaka), Leo (simha) and Virgo (kanyā) in the reverse order (utkramena). In the same manner, the day circles of Libra (tulā), Scorpio (vrścika) and Sagittarius (dhanuṣ) should be added towards the south [of the equator]. [The same rings belong also to] Capricorn (makara), Aquarius (kumbha) and Pisces (mina) in the reverse order."

[थ14] स्वाहोरात्रमण्डलेषु दक्षिणोत्तरायतानि सूत्राणि बध्रीयात्। तेषामर्धान्यपक्रमज्याः। मेषस्याहोरात्रमण्डलेनोन्मण्डलुस्य यत्र सम्पातस्तत्र सूत्रस्यैकमग्रं बद्धा मीनस्याहोरात्रोन्मण्डलुसम्पाते द्वितीयमग्रं बध्रीयात्। भूमध्यावभेदिसूत्रं विषुवता सह बध्रीयात, तस्य प्रथमसूत्रस्य च यत्र सम्पातस्तत्र प्रथमसूत्रार्ध भवति। एवमन्येषां सूत्राणामर्धानि। तानि सर्वाण्यहोरात्रापक्रमज्याः सन्ति। अराक्यत्वात्कचित्तु प्रदरर्यन्ते। यानि विक्षेपापक्रमस्वाहोरात्रमण्डलानि व्याख्यातानि [तानि न] प्रदर्रन्ते। अन्यथा कालसमो गोलो अ्रमयितुं न राक्यते, मण्डलबहुत्वात्। (11. 24-25, p. 241, and $11.1-7$, p. 242)

"One should tie (badhnīyat) on the day circles threads which stretch in the southnorth direction. Their halves are the [half-]chords of the declination (apakrama$j y \bar{a})$. He should tie one end of the thread at the intersection of the six o'clock circle (unmandala) and the day circle of Aries, and another end at the intersection of the six o' clock circle and the day circle of Pisces. He should tie the thread which passes through the middle of the earth (bhümadhyāvabhedin) to the equator. 


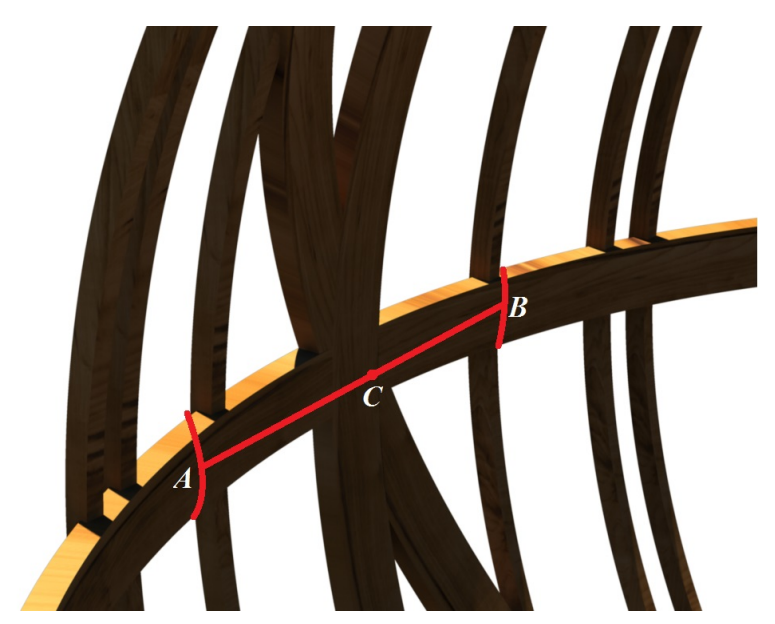

Figure for I1 14: Chords of the day circle. ${ }^{17}$

Where it intersects with the first thread, there is the mid-point (ardha) of the first thread. In the same manner, the halves of the other threads [are determined]. They are all the chords of declination of the day circles. Because it is impossible [to tie threads at all the necessary points], they are shown only at certain places (kvacit tu). These orbit [of the moon], ecliptic and day circles (vikșepapakramasvāhorātramandalāni), which have been commented upon, ${ }^{18}$ are not [all] shown [in this armillary sphere]. ${ }^{19}$ Otherwise, it would not be possible to rotate the armillary sphere according to time due to the abundance of the rings." 20

\footnotetext{
${ }^{17}$ The intersection of the six o'clock circle, which is identical with the horizon in Figure 14, and the day circle of Aries is marked $A$, the other intersection of the six o'clock circle and the day circle of Pisces is $B$. The intersection of the red thread $A B$ and the thread which passes through the middle of the earth to the equator (not shown in Figure for $\mathbb{I 1}$ 14) is $C$. Therefore $A C$ is the chord of declination of the day circles of Aries while $B C$ is the chord of Pisces.

${ }^{18}$ In the commentary on the ABH $4 \cdot 3$.

${ }^{19}$ Because the orbits of the moon and other planets and the day circles are said to be movable (sañcārin), they are not drawn in the figures in where those circles are not necessary.

${ }^{20}$ Bhāskara does not mention how the armillary sphere can be made to rotate according to time. We assume that he might have used a self-rotating device same as Āryabhața's self-rotating globe, for which see Ôhashi 1994: 260.
} 


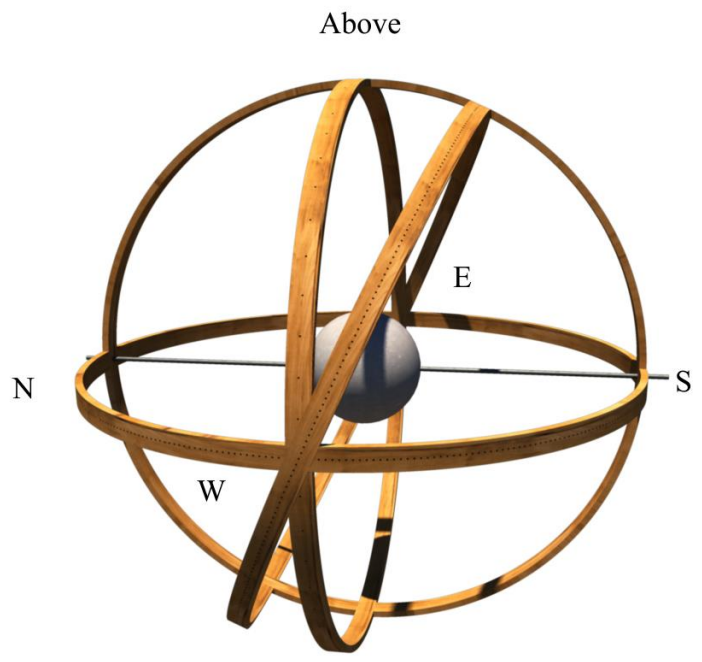

Below

Figure for II 15: Axis with the earth at the center.

[I115] अथ सुश्लक्ष्णामृज्वीमयःरालाकां गोपुच्छायतवृत्तां दक्षिणोत्तरस्वस्तिकावभेदिनीं निर्गतोभयाग्रां पज़रभारसहां निद्ध्यात्। तन्मध्ये भुवं समवृत्तां मृदाऽन्येन वा रचयेत्। एवमयमेक एव पअरः सर्वेषां ग्रहाणाम्। यस्माद्भिन्नकक्ष्यास्था अपि ग्रहाः एककक्ष्यागता एवोपलक्ष्यन्ते, तस्मादयमेवैकः पज़रः। अथवा सर्वेषामेव पृथक्पृथक्पश्जराः यावत्तावत्परिच्छिन्नस्वकक्ष्याप्रमाणा एव प्रदर्शायितव्याः। (11. 8-13, p. 242)

"Then he should insert a very smooth and straight iron rod (ayahśalākā) which is capable of bearing the weight of the shell of rings (pañjara), whose [two ends are] oval like the cow's tail (gopucchāyatavrttā $)^{21}$ and which pierces through the intersections at the south and the north in such a way that its extremities (agra) project out on both sides. In the middle of it (i.e., the rod) make a spherical ball (samavrttā) of clay or of any other [material to represent] as the earth. Thus, only one shell of rings is [enough] for all the planets. Although the planets are situated in different orbits, they are indeed seen as moving on a single orbit. Therefore only one shell of rings is [enough] here. Or, shells have to be shown separately (prthak prthak) for [each of] all the planets according to the size (pramanna) of their own different orbits (paricchinna-svakakșyā)."

\footnotetext{
${ }^{21}$ It is not clear why the rod here is described as a oval like a cow's tail. We imagine that the two ends of the rod are made swollen so that they can prevent the shell from slipping off.
} 


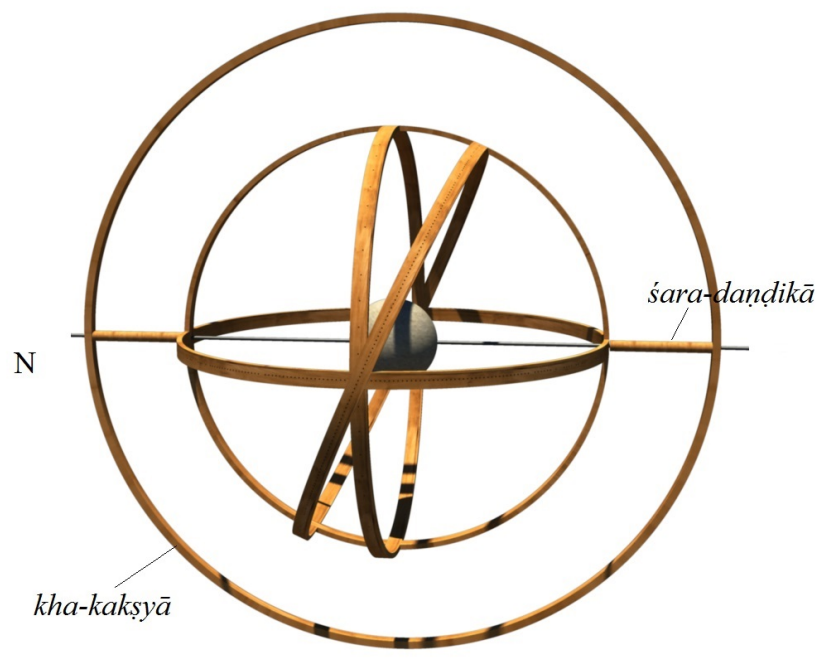

Figure for II 16: Addition of the orbit of the sky (kha-kakșyā).

[I16] अथवा पअ्जरस्य बहिः [दक्षिणोत्तर]स्वस्तिकयोरयःरालाकायां त्र्युुलां चतुरझुलां वा श्लक्ष्णां रारदुण्डकां निश्रत्डां निद्ध्यात्। ततो यावत्तावत्प्रमाणपरिच्छिन्नखकक्ष्यापरिकल्पितमुभयतश्चकार्धान्तरकृतवेधं [मण्डलं] दक्षिणोत्तरावगाहि निधाय तस्य मध्ये पज्जरं प्रवेशय तामयः रालाकामुभयत्र पार्श्ववेधौ प्रवेशायेत, यथा सा रारदुण्डका पज्रद्वयसीमावगाहिनी भवति। (11. 14-18, p. 242)

"Or one should firmly attach a three or four angula's long smooth stalk of reed (śara-dandika ) to the iron rod [projecting] out of the two intersections of the shell of rings. ${ }^{22}$ Then taking [a ring] of an appropriate dimension representing the orbit of the sky (kha-kaksya)), a ring in which [two] holes are made at distances equal to half the circumference (cakrārdhāntara) on both sides, one should place it in the south-north direction (dakșinottarāvagähin, lit., passing through the south and north [points]), and set the shell inside it by inserting the iron rod into the holes on both sides, so that that stalk of reed is embedded (avagāhin) in the boundary (i.e., interstice) of the two shells [along the iron rod]."

\footnotetext{
${ }^{22}$ The stalk of reed (sara, (Saccharum sara, Roxb.)) extends the length of the iron axis beyond the original shell on both sides. This addition is made in order to prevent the inner shell from shifting along the axis. This stalk of reed is hollow and smooth like a tube, so it would not hinder the spin of the axis.
} 


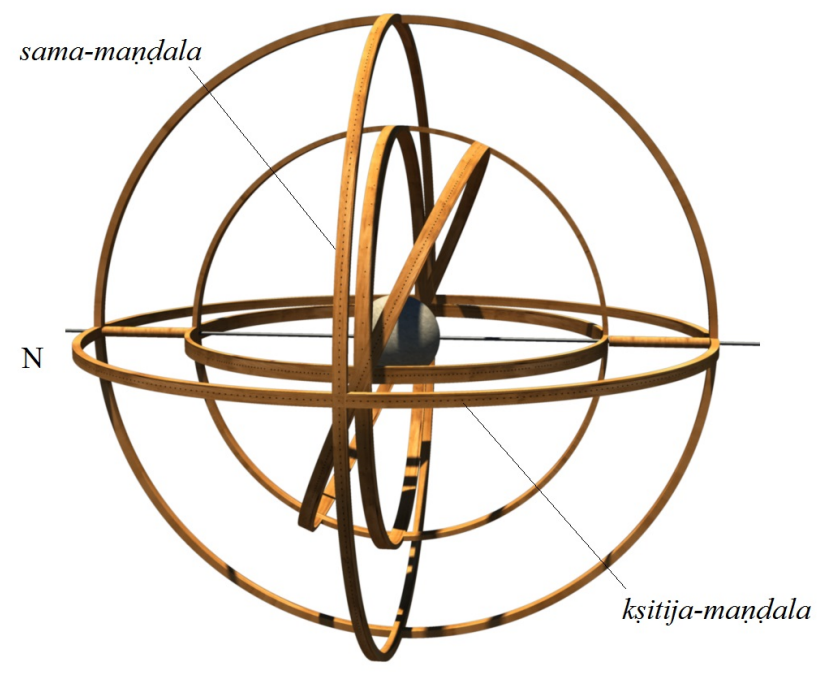

Figure for II 17: Gola set for use on the terrestrial equator.

[II 17] तावत्प्रमाणमेवान्यद्वृत्तं पूर्वापरावगाह्युपर्य् अघश्च जनितस्वस्तिकं पूर्ववन् निद्ध्यात्। तत्सममण्डलम्। पुनरपि तावद्वेवान्यन्मण्डलं परिकरवत् दिक्कतुष्टयजनितस्वस्तिकं दक्षिणोत्तरस्वस्तिकसम्पातकृतवेधमुभयत्र लोहरालाकां प्रवेइय निश्चलं निद्ध्यात्। तत्क्ष्किजिण्डलम्। एवमयं गोलो विषुवति सम एवावतिष्ठते। (1l.19-23, p. 242)

"One should affix as before another ring having the same size, which is embedded in the east and west directions, and in which intersections are made above and below. This is the prime vertical or east-west ring (sama-mandala, literally "equal[izing] circle"). Again, one should affix another ring of the same size like a girdle [around the two rings] so that four intersections are produced in each cardinal direction, make holes at the points of the intersection in the south and north, insert the iron rod into them and then make [the third ring] firm. This is the horizon ring (kșitija-mandala). In this way, this armillary sphere (gola) is set horizontally [in the case of a locality] on the [terrestrial] equator."

[I1 18] विषुवतः उत्तरेण यावानक्षस्तावत्सु भागेषु खगोलोत्तरस्वस्तिकादुपरि वेधं कारयेत, दक्षिणतश्च तावत्येवान्तरे [अधः] वेधः। पूर्ववेधाभ्यामयः रालाकां निष्कास्य स्वद्रेशाक्षभागप्रमाणपरिकल्पितवेधयोः प्रवेशायेत्। एवं स्वविषयाक्षप्रमाणेनावस्थितो गोलः, तत्र सर्वमेव प्रदर्शायेत्। (1l. 23-25, p. 242, and 1. 1, p. 243)

"One should have a hole made above the northern intersection of the sphere of the sky (khagola) by so many degrees as the [local] latitude is to the north of the equator; also one should make a hole in the south at the same interval [from 


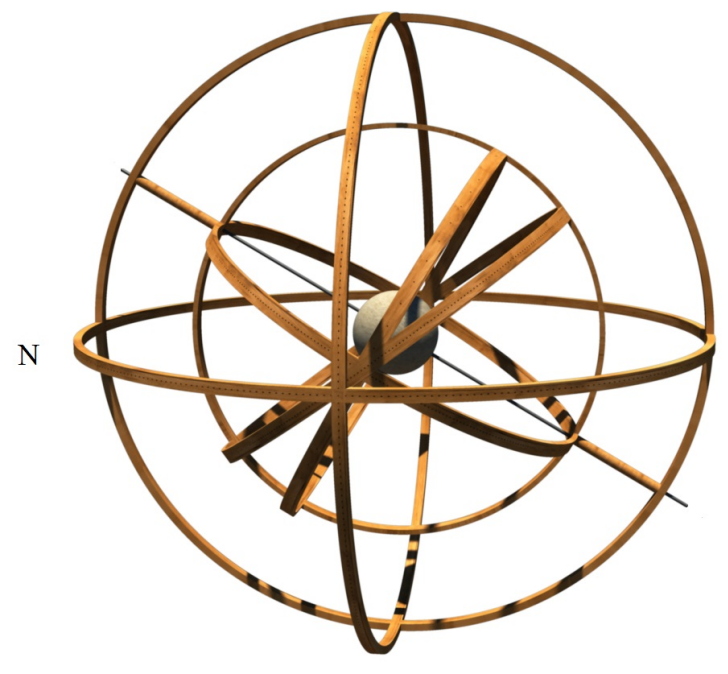

Figure for II 18: Adjusting the armillary sphere to the local latitude.

the southern intersection]. One should remove the iron rod from the two holes made before, and insert it into the two holes which are made according to the degrees of the local latitude (svadeśäkșa). In this manner, the armillary sphere is now correctly adjusted to the degrees of the local latitude. On this [armillary sphere] one should demonstrate everything."

[II 19] अथ खगोलग्रमाणम् एवान्यद्वृत्तमुभयतश्वकार्धान्तरकृतवेधमुत्तरतो निर्गतायः शालाकाग्रं प्रवेशायेत्। द्वितीयवेधं दक्षिणतो निर्गतायः रालाकाग्रं प्रवेशायेत्। तत्र तन्निश्रलं निधाय, तस्य पूर्वापरस्वस्तिकसम्पाते पूर्ववत्तिर्यग्भेदेन पूर्वापरस्वस्तिकयोर्निश्चलं तन् मण्डलं निद्ध्यात्। तदुन्मण्डलम् इत्याचक्षते। सर्वाण्येव वृत्तानि षष्टिरातत्रयभागाङ्कितानि कारयेत्। (1l. 2-6, p. 243)

"Now, one should insert another ring of the same dimension as the sphere $\mathrm{f}$ the sky, which has [two] holes on both sides at intervals of half the circumference, in such a way that the tip of the iron rod goes out of [the hole in] the north. One should insert [the same ring] in such a way that the other tip of the iron rod might go out of the other hole in the south. Having inserted it there firmly, he should make that ring firm at the east and west intersections by the oblique kind [of cutting] (tiryagbheda) at its two intersections of the joints on the east and west, as before. It is called the six o'clock ring (unmandala). All these rings should be made marked with 360 divisions."

[II 20] अन्ये पुनः समायामवनौ खगोलार्धप्रमाणमवटं खात्वा तत्र यथा क्षितिजमण्डलमुपरि भवति तथार्धनिमग्नं खगोलं निधाय दर्शायन्ति। (11. 7-8, p. 243) 


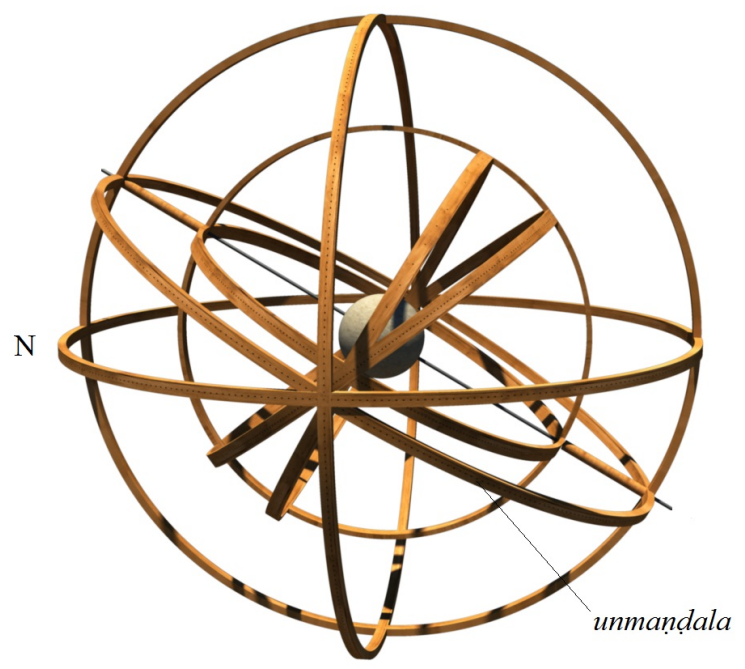

Figure for II 19: Addition of the six o'clock ring (unmandala).

"On the other hand, some people dig a hole in the level ground according to half the size of the sphere of the sky. Then they place the sphere of the sky there in such a way that its [lower] half is sunk [in the pit] so that the [entire] horizon ring (kșitija-mandala) might be above [the ground level]; [with this arrangement,] they make demonstrations."

[II 21] एवमयं काष्ठमयो गोलः क्रियते। काष्ठासम्भवे परिपक्काल्पसुषिरश्लक्ष्णवंशाइालाकावृत्तैर्वा गोलः क्रियते। एवं गोलं बध्वा सर्वमेवावरोषं शास्त्रे व्याख्यायते। (11. 8-11, p. 243)

"Thus this wooden armillary sphere is made. If wood is not available, then the armillary sphere can also be made with the rings of smooth pieces (śalāka $)$ of [split] bamboo (vamiśa) which has a narrow hollow channel (sușira) inside and which is completely dry (paripakva). After [explaining how to] construct the armillary sphere in this manner, all the rest will be explained in [the commentary on] the text [of the Âryabhatìya]."

\section{CONCLUSION}

In the preceding section we have followed Bhāskara's own words. I would like to add a few words on his method of constructing armillary sphere. The armillary sphere consists of two concentric shells with a clay terrestrial globe at the centre; the iron axis passes through the centres of all the three. The later writers call the 


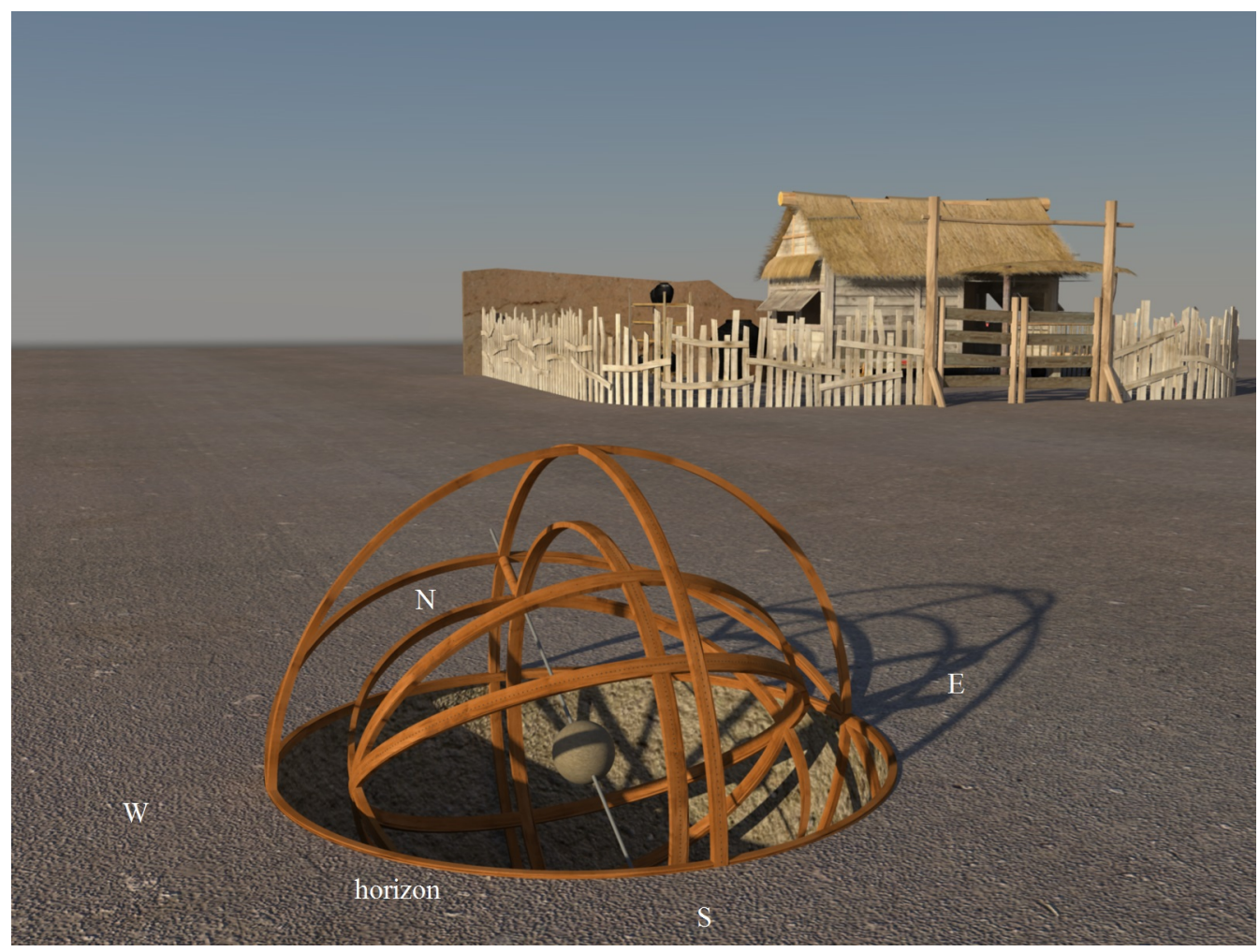

Figure for II 20: Placing the sphere of the sky in the ground.

inner shell "sphere of stars" (bhagola or nakṣatragola) and the outer shell "sphere of the sky" (khagola).

As mentioned in II 2, Bhāskara regards the armillary sphere as a fictitious construction to understand the real celestial sphere. Already at the beginning of the commentary he states: "the armillary sphere (gola) is a means (upaya) to demonstrate the revolution of the planets and the situation of the earth." ${ }^{23}$ Somewhat later, while commenting on Arryabhatīya 1.10, he asserts that,

the armillary sphere (gola) is a shell of stars (bhapañjara), in which the motion of the planets is understood because the armillary sphere (gola) is a tool for the perception (pratipatti-hetu) of the true motion of the planets. ${ }^{24}$

But besides measuring the chords of declination of the day circles by threads, Bhāskara does not mention other uses of the armillary sphere, whereas Lalla

\footnotetext{
${ }^{23} \mathrm{BAB}$ 1.1: गोलं ग्रहभ्रमणधरित्रीसंस्थानदर्शानोपायम्। Shukla 1976: 6.

${ }^{24} \mathrm{BAB}$ 1.10: भपज्जरो गोलः, तस्मिन्गोले तद्रहचरितं ज्ञात्वा, अवगम्य, ग्रहाणां स्फुटगतेः प्रतिपत्तिहेतुर्यतो गोलः। Shukla 1976: 42.
} 


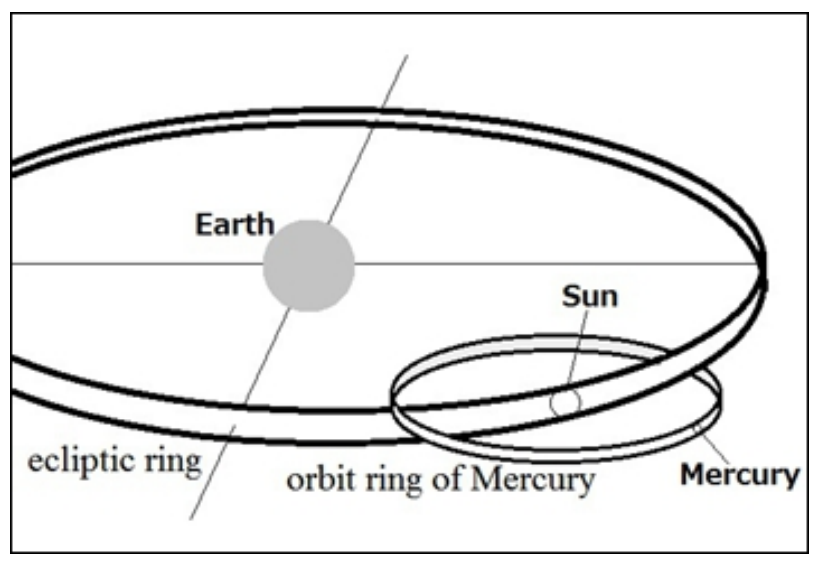

Adding the orbit of Mercury to the ecliptic.

teaches how to determine time and the lagna (the point of sunrise on the east horizon) with the armillary sphere. ${ }^{25}$

Moreover, Bhāskara does not explain clearly how to add the "vimandala" or the orbit rings of Mercury and Venus according to their śighrocca scales. Since these two are inferior planets which always appear near the sun, the rings of their orbits are not like those of the moon or of the other planets, which are akin to the ecliptic ring. The rings of the orbits of Mercury and Venus ought to be smaller and added to the armillary sphere as shown in the Figure above. But if they are so added, they would hinder the rotation of the rings in the inner shell of the armillary sphere.

${ }^{25}$ See Ôhashi 1994: 269. 


\section{ABBREVIATIONS}

ABH $\quad$ Aryabhațìya (Shukla, 1976)

вав Bhāskara's commentary on the Āryabhatīya (ibid.).

Bss Brāhmaspuțasiddhānta (Ikeyama, 2003).

\section{REFERENCES}

Bryant, W. W. (1907). A History of Astronomy. London.

Ikeyama, Setsuro (2003). "Brāhmasphuțasiddhānta (Ch. 21) of Brahmagupta with the Commentary of Pṛthūdaka. Critically Edited with English Translation and Notes". In: Indian Journal of History of Science 39. Supplement.

Ôhashi, Yukio (1994). "Astronomical Instruments in Classical Siddhāntas". In: Indian Journal of History of Science 29.2, pp. 155-313.

Pingree, David E. (1981). Jyotihśāstra: Astral and Mathematical Literature. Vol. 6.4. A history of Indian literature. Wiesbaden: Harrassowitz.

Sarma, K. V. (1997). "Armillary Spheres in India". In: Encyclopaedia of the History of Science, Technology, and Medicine in Non-Western Cultures. Ed. by Helaine Selin. London.

Shukla, K. S. (1976). Áryabhațìya, with the commentary of Bhāskara and Someśvara. New Delhi: Indian National Science Academy.

Yano, Michio (1980). “矢野道雄. 「アールヤバティーヤ (Āryabhațīya)」”. In: 『インド天文学·数学集 (Indo Tenmongaku Sugakusyu)』. 
Please write to 〈info@sayahna.org to file bugs/problem reports, feature requests and to get involved. Sayahna Foundation • JWRA 34, Jagathy • Trivandrum $695014 \bullet$ INDIA 